\title{
AVALIAÇÃO DO RISCO DE QUEDA DE ÁRVORES: PREVENÇÃO DE ACIDENTES NO CAMPUS DA UNICAMP
}

SIMPÓSIO DOS PROFISSIONAIS DA UNICAMP
CAMILA ALONSO SANTOS, ADRIANO GRANDINETI AMARANTE, LAURO DOS SANTOS, JURANDIR ALVES MOREIRA, JOSÉ BENEDITO DE CASTRO HENRIQUE

REIT - REITORIA;PREF - PREFEITURA GABINETE;PQECOL - PARQUE ECOLOGICO;
Introdução:

DOI: $10.20396 /$ sinteses.v0i7.11408

A queda de árvores no ambiente urbano é frequente em épocas de chuva, trazendo prejuízos materiais e imateriais. No início de 2015 foi registrado em um período de 15 dias a queda de 760 árvores no município de São Paulo. Esta situação trouxe a reflexão sobre a necessidade de um maior enfoque quanto a fitossanidade e outras questões relacionadas a arborização da Unicamp, que abriga cerca de 14.000 de diversas espécies, idade e em diferentes condições. Com esta motivação foi idealizado o Programa Árvores Saudáveis que abrange todas as questões relacionadas ao bom planejamento e manejo da arborização do campus e onde se instituiu a avaliação sistemática das árvores do campus, a fim de detectar possíveis riscos, orientar ações e prevenir acidentes envolvendo queda de galhos e de árvores.

\section{Metodologia:}

A avaliação é realizada por inspeção visual do sistema radicular, tronco e copa quanto a presença de pragas, doenças, ocos, injúrias mecânicas, relação de equilíbrio da árvore, vitalidade, condições locais e alvos potenciais caso a árvore ou galho venha a cair. Quando necessário, é realizada avaliação por ultrassom por pesquisadores da FEAGRI. Realiza-se o registro das árvores identificadas com risco de queda e orienta-se as intervenções.

\section{Resultados:}

Entre os anos de 2015 e 2018 foi realizada a inspeção em cerca de 3.400 árvores com necessidade de alguma intervenção. Dentre estas árvores foi detectado o risco e prevenida a queda de 356 indivíduos que estavam mortos, em declínio, com problemas fitossanitários ou danos que comprometessem a sua sustentação. Todas as ações preventivas foram realizadas eliminando assim o risco de acidentes que poderiam ter ocorrido envolvendo os indivíduos avaliados. A média de ocorrências de queda de árvores no campus entre 2015 e 2018 foi de 9 indivíduos por ano e ocorreu em plantas saudáveis que não resistiram a ação do vento ou chuva e em indivíduos que apresentaram algum problema no sistema radicular não passível de detecção pela inspeção visual. Este ainda é um desafio a ser enfrentado, pois nem sempre o problema existente nas raízes de uma árvore se reflete em sua copa ou em sinais na superfície, sendo difícil a detecção do risco neste caso. Ainda assim, a ocorrência de queda de árvores é baixa, se compararmos o Campus com outras regiões do município de Campinas. Além destes resultados, a avaliação das árvores possibilitou a identificação de fatores que influenciaram na fragilidade dos indivíduos, oferecendo informações que subsidiam o melhor planejamento para plantios futuros.

\section{Considerações finais:}

A arborização da Unicamp é um patrimônio botânico e cultural que contribui para a melhor qualidade do ar, redução do calor, conservação da biodiversidade, saúde e bem-estar humano. O bom manejo desta vegetação é essencial para assegurar estes benefícios sem que a mesma apresente risco às pessoas e ao patrimônio, ficando evidente a importância de monitoramento contínuo e cuidados das árvores existentes associado ao planejamento adequado de novos plantios.
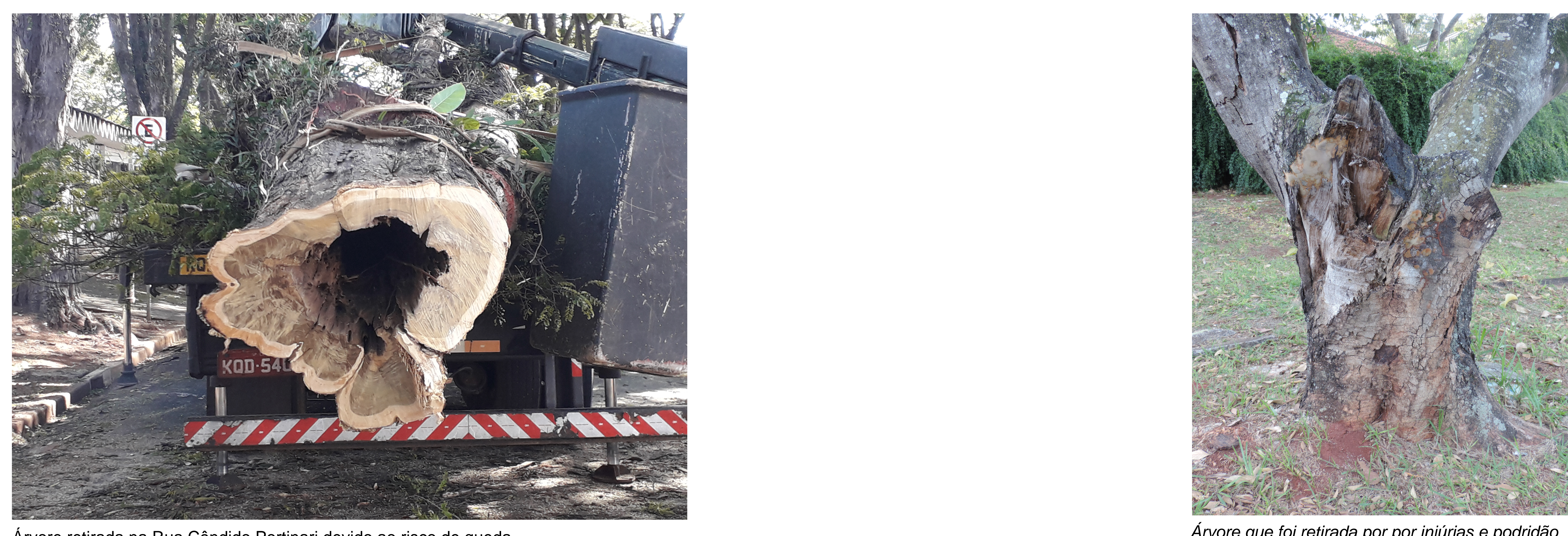

Arvore que foi retirada por por injúrias e podid

Anvore retirada na Rua Cândido Portinari devido ao risco de queda. 